deal with children's problems and achievements. The only general suggestion for improving the films is the use of colour, which is costly.

The British Film Production Fund, Ltd., has made grants totalling $£ 529,883$ to the Foundation. Fundamentally, an entertainment film for children cannot be a low-priced production. Receipts from the distribution of films are now sufficient to pay for the cost of release prints, and the balance is paid to the British Film Production Fund. These receipts can never be large because admission prices to children's film shows are low. The Foundation's value to the industry and the community cannot be judged in terms of money since its primary object is to promote appreciative and intelligent film-going by youthful audiences. For this reason the British film industry as a whole supports the Foundation with an annual grant from the Fund.

\section{FRESH WATER FROM SALT WATER}

\footnotetext{
T
}

HE production of fresh water from salt water must be one of the oldest technical problems. It is currently receiving a degree of widespread yet concentrated attention which surpasses anything previously devoted to it. The reasons for this are substantially the same the world over; chief among them is the fact that living standards are rising generally and that fresh-water consumption per head of population is a basic and reliable index to the standard of living of a community. As the degree of industrialization increases and living standards rise, so does the demand for water; reservoir capacity becomes inadequate, the drain on artesian wells increases (see Nature of Dec. 17, p. 1133). The consequence of the latter effect depends on the situation. In coastal areas it may lead to infiltration of sea water, in other areas to a raised salt content as the increased pumping lowers the level of the underground reserve. The possibility of demineralization must be considered in both cases. For alternative sources of water one may turn, depending on one's location, to new wells, which may themselves be brackish; to new reservoir capacity, if this is feasible and if the rainfall justifies it ; to more or less long-distance pumping of supplies from distant sources; or in extreme cases to sea water. All these possibilities are likely to be expensive; the first may, and the last certainly will, involve demineralization procedures.

Some indication of the interest in these procedures has been described by D. J. Neville-Jones (Research, 8 , No. 11 ; November 1955). Since some publicity was given to the United Kingdom participation in the Organization for European Economic Co-operation discussions on the subject a year or two ago, scores of inquiries have been received in London from places ranging from Norway to Australia, from Hong Kong to the Bahamas. The United Kingdom itself is interested, despite its notorious rainfall, because the inexorably increasing demand is leading to sea water infiltration in such areas as the Thames Estuary; it is becoming increasingly difficult to find uncontaminated alternative sources which do not. involve expensive long-distance pumping. Germany has similar problems in the lower reaches of the Rhine. The Netherlands is concerned because, by the nature of its low-lying territory, sea water infiltration is always a likely problem. Australia and South Africa are developing territories in which sea water or other highly saline waters have to be considered. The rapid industrial development of the United States of America is leading to water shortages in the vast interior territories where in many cases only brackish water is available.

The problem is not simple to define, or solve. This will depend on a multiplicity of factors such as the availability and cost of energy sources, the mineral content of the raw matter and the purpose for which the fresh water is required, that is, the price which can be paid for it. Each case will have to be examined according to the local circumstances.

\section{LABORATORY TECHNICIANS}

A

SUB-COMMITTEE of the Science Masters' Association has been considering the place of laboratory technicians in secondary schools and has now issued a report. The number of schools with laboratory technicians is far too small, and there is urgent need for more technicians to be employed. This is particularly important since the problem of the recruitment of laboratory technicians in schools is ralated to that of the shortage of science teachers. The sub-committee suggests, however, that the establishment of a national scheme for the provision of laboratory assistance on an adequate scale to all schools where a significant amount of science is taught is a problem in its own right.

The teacher without a laboratory technician finds himself with less time than he should have for his normal teaching duties, the planning of his work and for the development of new apparatus and techniques. He has no time for designing and arranging practical work which can be carried out by the pupils themselves, and all too frequently lessons become "chalk and talk". Such a wasteful use of the time of seience teachers must be deplored.

The sub-committee considers that the duties of a school laboratory technician call for a considerable degree of skill and a good deal of training. Much work has been done by various organizations on the formulation of courses of study for laboratory technicians. For schools the most suitable of these is that leading to the examination for the Laboratory Technician's Certificate of the City and Guilds of London Institute. The facilities for study are expanding; twenty-four centres, mostly technical colleges, now offer courses of instruction recognized by the City and Guilds of London Institute, and the number of candidates entering for the examination has increased from eighteen in 1951 to ninety-six in 1954.

The sub-committee realizes that recruitment is one of the most difficult parts of the problem, but believes that science teachers would be able to encourage suitable boys and girls in their own schools to apply for the posts if they could assure their pupils that salary, prospects and promotion, good working conditions -hours, holidays, superannuation, sick pay-facilities for study, and status were such as to compete with those obtainable in other educational institutions and industry.

Suggestions are also made as to the scale of assistance which might be given to various schools, suitable scales of remuneration and the duties which could be performed by laboratory technicians. 